Applied Hospital Administration (First Edition) published by Lt Col A Chakravarhy, Officers Training School, AMC, Centre and School, Lucknow pages 446, price Rs.384/-.

7 he first edition of "Applied Hospital Administration" published by OTS, AMC Centre and School deals with administrative issues related to Service Hospitals in an elaborate manner.

While written primarily from the point of view of a "Handbook for Commanding Officers", it also addresses the needs of any officer engaged in administrative duties in a hospital.

The book is divided into six parts - general administration of service hospital, hospital logistics management, human resource management, hospital asset management, patient care management and management for total consumer satisfaction.

Notes on Medical Microbiology by MC Timbury, AC McCartney, B Thakker and KN Ward. Published by Churchill Living Stone 2002, soft bound, Rs.2174/-, ISBN-0-443-07164-0.

Tn the current scenario of increasing epidemics, this book usefully updates its readers in a concise and comprehensive manner, details of various microbes and their diseases. The combination of clinical picture in relation to the microbe has been well brought out in the chapter on bacterial and viral diseases. The Chapter on special infection problems, highlights important issues faced by health
The book cites up-to-date policy letters and instructions that govern various areas of operations in a service hospital. The book also refers to current concepts in hospital management and offers practical suggestions for effective and efficient management of hospitals. Overall the book is well written and the author has a good knowledge of the subject and the ability to present the subject with clarity and usefulness.

The book is recommended in conjunction with existing policies and procedures that govern administration of service hospitals.

Contributed by:

Col M Dayananda

Prof \& Head, Dept of Hospital Administration, AFMC, Pune-40.

care workers. However, section pertaining to antibiotic usage and guidelines to formulate an antibiotic policy could have been dealt with in more detail. The addition of sections on Mycology and Parasitology has made the book complete on all aspects pertaining to Infectious diseases.

Contributed by:

Lt Col KK Lahiri

Reader, Dept of Microbiology, AFMC, Pune-40.

\title{
Events Calendar
}

$08^{\text {th }}-09^{\text {th }}$ October, 2005

\section{Retina Update}

Venue : Department of ENT,

Armed Forces Medical College

Pune-40.

Contact Person : Col RP Gupta (Organising Secretary)

Tel. : 91-020-26306035,91-020-26306041

e-mail : retinaupdate2005@yahoo.co.in

\section{$15^{\text {th }}-16^{\text {th }}$ October, 2005}

\section{XVIth RAJ APICON 2005}

Venue : Dr. SN Medical College, Jodhpur

Lt Col (Dr.) Pratap Sanchetee (Retd)

Organising Secretary

Sanchetee Hospital, 429 Pal Link Road, Jodhpur 342008.

Tel. : 0291-2757610, Mobile : 093147-45610

e-mail : pratapsanchetee@yahoo.o.in $19^{\text {th }}-23^{\text {rd }}$ October, 2005

XXIV National Congress of Indian Association of Medical

Microbiologist

MICROCON - 2005

Venue : Sri Ramchandra Medical College and Research Institute, Chennai 600116.

Pre-conference Workshop : $19^{\text {th }}-20^{\text {th }}$ October 2005

Congress : $21^{\text {st }}-23^{\text {rd }}$ October 2005

$12^{\text {th }}-13^{\text {th }}$ November, 2005

Surgery Conference - 2005 with Laparoscopy Workshop

(Role of Open Surgery in the Era of Laparoscopy)

Contact person: Col Rajan Chaudhary, VSM

(Organising Secretary)

Department of Surgery,

Armed Forces Medical College, Pune-40

Tel. : 91-020-26306017 (O), 91-020-26306317(R)

Mobile:9850232637 Fax:020-26874759

e-mail : rajan5855@rediffmail.com 